\title{
Hypothalamic-pituitary abscess
}

\author{
P. D. MOHR \\ B.Sc., M.R.C.P.
}

\section{Department of Neurology, The Queen Elizabeth Hospital, Birmingham B15 2TH}

\begin{abstract}
Summary
A case of hypothalamic-pituitary abscess is described, and previous case reports discussed. The clinical picture is one of hypopituitarism, a fluctuating clinical course with attacks of meningism, and a background of sphenoid sinusitis.
\end{abstract}

\section{Introduction}

Abscesses of the diencephalon are extremely rare. This case report gives details of a patient with panhypopituitarism due to an abscess of the hypothalamus and pituitary gland. The clinical, endocrinological, and radiological findings are described and and compared with previous case reports. A common pattern of signs and symptoms and a relationship to sphenoid sinusitis can be recognized.

\section{Case report}

The patient was a 58-year-old single woman. Over a period of 1 year she had had seven attacks of headache, drowsiness, and neck stiffness. Each bout lasted for 3 or 4 days, and on two occasions was associated with a watery nasal discharge. The attacks became progressively more severe, and laterally these alternated with episodes of severe polyuria and polydipsia lasting for 2-3 weeks. There was no significant past medical history or family history. Her menstrual periods were normal until the menopause at 42 years of age.

She was admitted to hospital in June 1972. On examination she was alert with a pale skin, sparse hair, and a blood pressure of 105/60. A lower quadrantic bitemporal field defect was shown on perimetry, but there was no other neurological deficit. Two days after admission she became drowsy, with marked neck stiffness, and intense headache. Tentorial coning was suspected, and she was accordingly given intravenous dexamethasone, to which she responded satisfactorily. Skull X-rays were normal, and the pituitary fossa was not enlarged. Air-ventriculography showed a dubious filling defect of the floor of the third ventricle, but further ventriculography a few days later, with a contrast dye, was considered to be normal. The ventricular cerebro-spinal fluid contained 400 poly- morphs, but culture was sterile. An electroencephalogram done during the phase of headache and meningism showed generalized delta activity, which subsequently improved. A chest X-ray, and brain scan were normal.

It was during a second admission in September 1972, that the patient had her most severe attack, beginning with headache, and soon going on to coma, with board-like neck stiffness, and signs of decerebrate rigidity. During this episode the blood sugar was found to be $13 \mathrm{mg} \%$ and she responded well to intravenous dextrose.

Biochemical and haematological investigations showed evidence of hypopituitarism. Hb $11 \mathrm{~g}$, ESR 40 , serum osmolarity $306 \mathrm{mmol} / \mathrm{kg}$, urine osmolarity $70 \mathrm{mmol} / \mathrm{kg}$, PBI $3.2 \mu \mathrm{g} \%$, plasma cortisol at 9.00 a.m. was $6 \mu \mathrm{g} \%$ and at midnight was $7 \mu \mathrm{g} \%$. Long and short synacthen tests were normal, but growth hormone levels during the period of hypoglycaemia did not exceed $4 \mu \mathrm{u} / \mathrm{ml}$. Stimulation of the pituitary gland with TRH showed some response with a rise of TSH to $6.9 \mu \mathrm{u} / \mathrm{ml}$.

It was clear that the patient had hypopituitarism, secondary to a hypothalamic lesion. In spite of the ventriculographic findings it was considered that a granulomatous process located in the peri-infundibular and chiasmatic region was most likely, but no evidence of its nature emerged. Sarcoid is known to attack this area rarely, but there was nothing to support the diagnosis of sarcoidosis in this particular case, as the chest X-ray was normal, the Kveim test was negative, and liver biopsy normal. She was discharged on thyroxine and hydrocortisone as replacement endocrine therapy, and made good progress until December 1972, when she became abruptly ill, and passed into a coma; she was admitted to hospital elsewhere, and died in the space of $24 \mathrm{hr}$.

Autopsy showed atrophy of the thyroid and adrenal glands. The pituitary gland was displaced by an intrasella abscess containing pale green pus, which was continuous with a $6 \mathrm{~mm}$ diameter abscess cavity in the hypothalamus (Fig. 1); the basal cisterns were filled with purulent cerebro-spinal fluid. No organism was cultured from this material. Histology showed a pyogenic membrane enclosing the abscess 


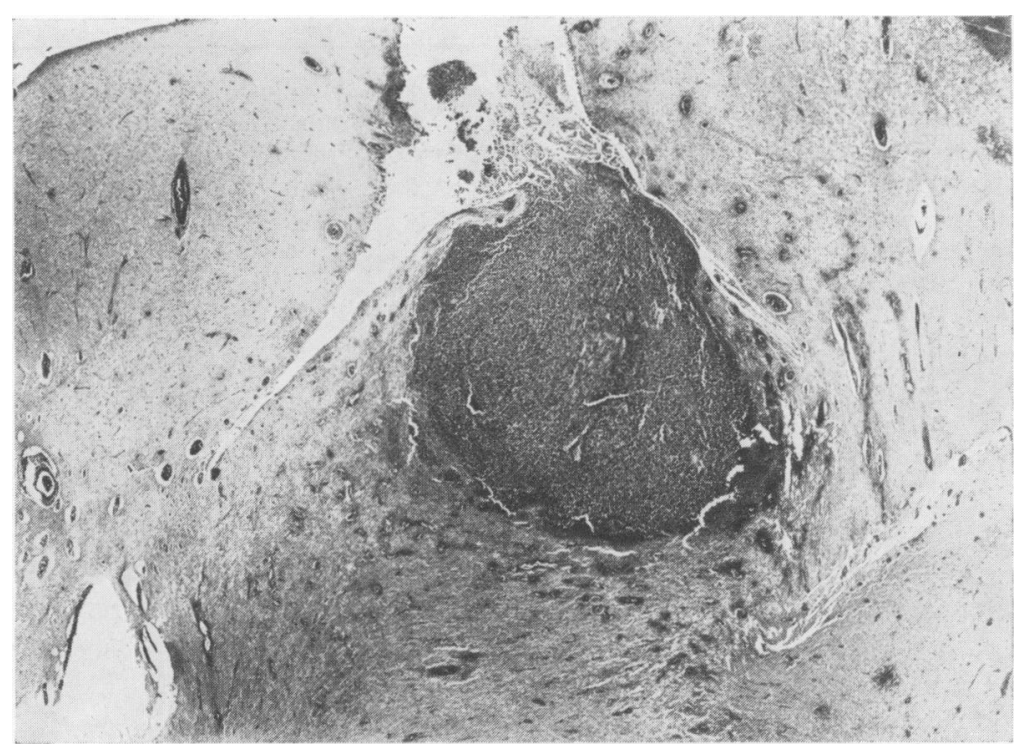

Fig. 1. A coronal section through the hypothalamus showing the abscess alongside the third ventricle. $\times 10$.

in the hypothalamus and pituitary gland. The abscess contained a mixture of polymorphs, lymphocytes, and plasma cells, and the pituitary gland also showed areas of fibrosis interspaced with islands of normal pituitary tissue. The meninges showed evidence of acute inflammation, and arteries penetrating the base of the brain also showed an inflammatory arteritis.

\section{Discussion}

Hypothalamic and pituitary abscesses are rare. This is clearly demonstrated in the publications of Evans (1931), Gates, Kernohan and McCraig (1950), Jooma, Pennybacker and Tutton (1951), Loeser and Scheinberg (1957), Liske and Weikers (1964), and Garfield (1969) who have all reported large series of brain abscesses, yet none mentions abscess formation in the hypothalamus or pituitary gland, and Krayenbuhl (1967) found only one case of pituitary abscess in a series of 130 patients with cerebral abscesses.

Nevertheless, isolated reports of pituitary abscess can be traced, and these are shown in Table 1. All showed features of hypopituitarism, with the exception of the case of Nelson et al (1967) which was very acute. Diabetes insipidus was specifically noted in the case reports by Svien and Love (1942), Paillas and Aymard (1956), Milenkovic (1961), and Lindholm, Rassmussen and Kersgaard (1973). The pituitary fossa was enlarged in ten cases, and thirteen cases had visual field defects, usually bitemporal hemianopias. Indeed, the initial diagnosis in many of these cases was that of a pituitary tumour, and the true diagnosis was only discovered at operation or autopsy. The cases of Asenjo (1953) and Whalley (1952) were associated with pituitary adenomas, but the presence of sphenoid sinusitis and of pneumococci in Asenjo's case would indicate that there was true abscess formation, and not simply liquefaction due to spontaneous white infarction in a pituitary adenoma, a well recognized phenomenon recorded by Jefferson and Rosenthal (1959), and others, a process loosely spoken of by neurosurgeons as 'sterile abscess' of the pituitary. It is interesting to note that many of the cases have had a prolonged intermittent course with episodes of meningism and drowsiness, very similar to the patient reported now; the similarity is especially striking in the examples of Bouché et al. (1964) and Paillas and Aymard (1956). However, there seems to be no previous account of hypoglycaemia as a feature.

Pneumococci were isolated by Asenjo (1953) and Paillas and Aymard (1956); enterococci were isolated by Nelson et al. (1967); and staphylococci were isolated by Lindholm et al. (1973). The pus obtained in all other cases was sterile. The cerebrospinal fluid was examined in five cases, and was noted to contain an increased number of polymorphs, but was always sterile on culture.

The relationship of hypophyseal abscesses to sphenoid sinusitis was stressed by Tweed (1938) in his paper on the neurological complications of sphenoid sinusitis. He reviewed 126 cases, and found 
TABLE 1

\begin{tabular}{|c|c|c|c|c|c|c|c|c|}
\hline Case & Age/sex & $\begin{array}{l}\text { Hypo- } \\
\text { pituitarism } \\
\text { present }\end{array}$ & $\begin{array}{l}\text { Visual } \\
\text { field } \\
\text { defect }\end{array}$ & $\begin{array}{l}\text { Large } \\
\text { pituitary } \\
\text { fossa }\end{array}$ & $\begin{array}{l}\text { Sphenoid } \\
\text { sinusitis }\end{array}$ & $\begin{array}{l}\text { Organism } \\
\text { in pus }\end{array}$ & Treatment & Outcome \\
\hline $\begin{array}{l}\text { Present case } \\
\text { Nelson } \text { et al., } 1967\end{array}$ & $\begin{array}{l}58 / F \\
27 / F\end{array}$ & $\begin{array}{l}\text { Yes } \\
\text { No }\end{array}$ & $\begin{array}{l}\text { Yes } \\
\text { No }\end{array}$ & $\begin{array}{l}\text { No } \\
\text { No }\end{array}$ & $\begin{array}{l}\text { Yes } \\
\text { Yes }\end{array}$ & $\begin{array}{l}\text { None } \\
\text { Entero- } \\
\text { coccus }\end{array}$ & Penicillin & $\begin{array}{l}\text { Died } \\
\text { Died }\end{array}$ \\
\hline $\begin{array}{l}\text { Bouche et al., } 1964 \\
\text { Milenkovic, } 1961 \\
\text { Milenkovic, } 1961 \\
\text { Whalley, } 1952\end{array}$ & $\begin{array}{l}43 / \mathrm{F} \\
19 / \mathrm{F} \\
32 / \mathrm{F} \\
50 / \mathrm{M}\end{array}$ & $\begin{array}{l}\text { Yes } \\
\text { Yes } \\
\text { Yes } \\
\text { Yes }\end{array}$ & $\begin{array}{l}\text { Yes } \\
\text { Yes } \\
\text { Yes } \\
\text { Yes }\end{array}$ & $\begin{array}{l}\text { No } \\
\text { Yes } \\
\text { Yes } \\
\text { Yes }\end{array}$ & $\begin{array}{c}\text { Yes } \\
? \\
? \\
\text { Yes }\end{array}$ & $\begin{array}{l}\text { None } \\
\text { None } \\
\text { None } \\
\text { None }\end{array}$ & $\begin{array}{l}\text { Surgery } \\
\text { Surgery } \\
\text { Surgery } \\
-\end{array}$ & $\begin{array}{c}\text { Recovered } \\
\text { Recovered } \\
\text { Recovered } \\
\text { Died }\end{array}$ \\
\hline $\begin{array}{l}\text { Paillas and Aymard, } \\
1956 \\
\text { Paillas and Aymard, }\end{array}$ & $\begin{array}{l}53 / F \\
33 / F\end{array}$ & $\begin{array}{l}\text { Yes } \\
\text { Yes }\end{array}$ & $\begin{array}{l}\text { Yes } \\
\text { Yes }\end{array}$ & $\begin{array}{l}\text { Yes } \\
\text { Yes }\end{array}$ & $\begin{array}{l}? \\
?\end{array}$ & $\begin{array}{c}\text { None } \\
\text { Pneumo- }\end{array}$ & $\begin{array}{c}\text { Surgery } \\
\text { Penicillin, }\end{array}$ & $\begin{array}{c}\text { Died } \\
\text { Recovered }\end{array}$ \\
\hline $\begin{array}{l}1956 \\
\text { Asenjo, } 1953\end{array}$ & $44 / M$ & Yes & Yes & Yes & Yes & $\begin{array}{l}\text { coccus } \\
\text { Pneumo- } \\
\text { coccus }\end{array}$ & $\begin{array}{l}\text { Surgery } \\
\text { Penicillin, } \\
\text { Surgery }\end{array}$ & Recovered \\
\hline $\begin{array}{l}\text { Barrada et al., } 1952 \\
\text { Svien and Love, } 1942\end{array}$ & $\begin{array}{l}42 / \mathrm{M} \\
34 / \mathrm{F}\end{array}$ & $\begin{array}{l}\text { Yes } \\
\text { Yes }\end{array}$ & $\begin{array}{l}\text { Yes } \\
\text { Yes }\end{array}$ & $\begin{array}{l}\text { Yes } \\
\text { Yes }\end{array}$ & $\begin{array}{l}? \\
?\end{array}$ & $\begin{array}{l}\text { None } \\
\text { None }\end{array}$ & $\begin{array}{l}\text { Surgery } \\
\text { Sulphonamides, } \\
\text { Surgery }\end{array}$ & $\begin{array}{l}\text { Recovered } \\
\text { Recovered }\end{array}$ \\
\hline $\begin{array}{l}\text { Tweed, } 1938 \\
\text { Krayenbuhl, } 1967 \\
\text { Lindholm } \text { et al., } 1973\end{array}$ & $\begin{array}{l}70 / \mathrm{M} \\
34 / \mathrm{M} \\
19 / \mathrm{F}\end{array}$ & $\begin{array}{l}\text { Yes } \\
\text { Yes } \\
\text { Yes }\end{array}$ & $\begin{array}{l}\text { Yes } \\
\text { Yes } \\
\text { Yes }\end{array}$ & $\begin{array}{l}\text { No } \\
\text { Yes } \\
\text { Yes }\end{array}$ & $\begin{array}{c}\text { Yes } \\
? \\
?\end{array}$ & $\begin{array}{l}\text { None } \\
\text { None } \\
\text { None }\end{array}$ & $\begin{array}{l}\text { Surgery } \\
\text { Antibiotics, }\end{array}$ & $\begin{array}{c}\text { Died } \\
\text { ? Recovered } \\
\text { Recovered }\end{array}$ \\
\hline Lindholm et al., 1973 & $17 / \mathrm{F}$ & Yes & Yes & No & ? & $\begin{array}{l}\text { Staphylo- } \\
\text { cocci }\end{array}$ & $\begin{array}{l}\text { Surgery } \\
\text { Antibiotics, } \\
\text { Surgery }\end{array}$ & Recovered \\
\hline
\end{tabular}

six cases of definite pituitary abscess, and a possible further ten. Most were examined at post-mortem, but unfortunately full clinical details are only available in the case listed in Table 1 . Infection of the sphenoid sinus was present in six of the cases reviewed in Table 1, but the state of the sinus was not mentioned in the remainder. However, it is reasonable to conclude that abscesses in the region of the diencephalon are nearly always secondary to infection in the site of the sphenoid sinus.

The radiology of pituitary abscesses has been discussed by Nelson et al. (1967), who consider that bilateral carotid angiograms give the most information by demonstrating lateral displacement of the carotid siphon, with segmental spasm of the cavernous portion of the internal carotid artery. Paillas and Ayward (1956) have also recorded changes in the carotid angiogram, as well as abnormalities on air-encephalography. The ventriculograms done in the present case were regarded as normal, though in retrospect there is probably a filling defect of the floor of the third ventricle. Apart from contrast studies it is important to obtain good plain radiological views of the sphenoid sinus; in the present case the sinus was not clearly visualized in all of the films, though it was accepted as normal, perhaps on insufficient evidence; the presence of a fluid level is of inescapable significance.

The prognosis is fairly good, providing the diagnosis is made, and the rational treatment would appear to be antibiotics and surgery, either by the direct approach (Svien and Love, 1942), or transseptally (Bouche et al., 1964).
In conclusion it may be said that hypothalamic and pituitary abscesses are rare, but must be considered as a possible complication of sphenoidal infection. Whilst they may simulate pituitary tumours, a more outstanding clinical feature that emerges from study of the literature is the fluctuating course of the disease with episodes of meningism, which may be explained by the abscess repeatedly leaking pus into the subarachnoid space. One may speculate that the associated endocrine disturbance consequent on pituitary damage may cause impairment of inflammatory responses, and thereby explain the absence of pyrexia in many cases, including the present example. The diagnosis of hypophyseal abscess should be suspected in unusual cases of hypopituitarism, even when evidence of sphenoid sinusitis is not outspoken.

\section{Acknowledgments}

I owe thanks to Dr M. Jefferson for permission to report this patient, and for encouragement in writing it up, to Professor W. T. Smith for his comments on the histology, and to Dr V. H. Bowers for details of the post-mortem findings.

\section{References}

Asenjo, A. (1953) Operation on a pneumococcal abscess in a transitional pituitary adenoma. Acta neurochirurgica (Wien), 3, 100.

Barrada, V., Guinena, Y., Abd Einaby, S. \& Taher, Y. (1952) Intra-sellar abscess simulating chromophobe adenoma. Journal of the Royal Egyptian Medical Association, 35, 106.

Bouché, J., Guiot, G., Frenche, G.A. \& Cotin, G. (1964) Pituitary abscess; the low trans-septal approach. Annales d'oto-laryngologie (Paris), 81, 834. 
Evans, W. (1931) The pathology and aetiology of brain abscess. Lancet, i, 1231.

GARDFIELD, J. (1969) Management of supra-tentorial intracranial abscess: A review of two hundred cases. British Medical Journal, ii, 7.

Gates, E.M., Kernohan, J.W. \& McCraig, W. (1950) Metastatic brain abscess. Medicine, 29, 71.

JefFerson, M. \& Rosenthal, F.D. (1959) Spontaneous necrosis in pituitary tumours. (Pituitary apoplexy). Lancet, i, 342.

Jooma, O.V., Pennybacker, J.B. \& Tutton, G.K. (1951) Brain abscess: Aspiration, drainage or excision. Journal of Neurology, Neurosurgery and Psychiatry, 14, 308.

Krayenbuhl, H.A. (1967) Abscess of the brain. Clinical Neuro-surgery, 14, 25.

Lindholm, J., Rasmussen, P. \& KorsgaARd, O. (1973) Intra-sellar or pituitary abscess. Journal of Neurosurgery, 38, 616.

Liske, E. \& Weikers, N.J. (1964) Changing aspects of Brain Abscesses. Neurology (Minneapolis), 14, 294.
Loeser, E. \& Scheinberg, L. (1957) Brain abscesses. Neuro$\log y$ (Minneapolis), 7, 601.

Milenkovic, P. (1961) Abscesses in the hypophyseal cavity. Srpski archiv za celokupno lekarstvo, 89, 883.

Nelson, D.A., Holloway, W.J., Karaeneff, S.C. \& GolDENBERG, H.I. (1967) Neurological syndromes produced by sphenoid sinus abscess with neuroloradiologic review of pituitary abscess. Neurology (Minneapolis), 17, 981.

Paillas, J.E. \& Aymard, J. (1956) Les abcès de l'hypophyse. Presse Médicale, 64, 1081.

Svien, A.J. \& Love, J.G. (1942) Abscess within the sella turcica simulating a pituitary tumor: Surgical cure. Proceedings of Staff Meetings of the Mayo Clinic, 17, 497.

TweED, R.W. (1938) Meningitis from the sphenoid sinus. Archives of Otolaryngology, 28, 589.

Whalley, N. (1952) Abscess formation in a pituitary adenoma. Journal of Neurology, Neurosurgery and Psychiatry, 15, 66.

\title{
Effect of hypocalcaemia on glucose tolerance, insulin release and free fatty acid levels in human subjects
}

\author{
S. BANSAL \\ M.D. \\ S. N. A. RIZVI
M.D. \\ M. B. RAO \\ M.D., M.R.C.P. \\ H. VAISHNAVA \\ F.R.C.P.E. \\ Metabolism and Endocrinology Unit, Department of Medicine, Maulana Azad Medical \\ College and Associated Irwin and G. B. Pant Hospitals, New Delhi, India
}

\section{Summary}

Eight patients with hypocalcaemia who presented with frank or latent tetany due to parathyroid insufficiency or nutritional osteomalacia were studied. Their serum calcium ranged from 6.85 to $7.7 \mathrm{mg} / 100 \mathrm{ml}$ (mean $7 \cdot 33 \pm 0 \cdot 36 \mathrm{mg} / 100 \mathrm{ml}$ ). In six of them, serum calcium after treatment varied from 8.4 to $9.2 \mathrm{mg} / 100 \mathrm{ml}$. In ten healthy normal subjects the serum calcium levels were $9.0-10.2 \mathrm{mg} / 100 \mathrm{ml}(9.50 \pm 0.47 \mathrm{mg} / 100 \mathrm{ml})$. The blood glucose levels during a $3 \mathrm{hr}$ oral GTT were significantly elevated during hypocalcaemia and returned to normal levels after treatment. Serum insulin levels were low at 60 and $120 \mathrm{~min}$ after the administration of glucose in hypocalcaemia but returned to normal once the serum calcium levels were above $8.4 \mathrm{mg} / 100 \mathrm{ml}$. The FFA levels were high during the low calcium state and reached normal levels after treatment. The above studies suggest that an optimal level of serum calcium is essential for glucose-induced insulin release.

Reprints requests: Dr S. N. A. Rizvi, Maulana Azad Medical College and Associated Hospitals, New Delhi, India.

\section{Introduction}

Many 'secretary cells', which store their products in granules or vesicles, need extracellular ionic calcium for the release of their secretions (Rasmussen, 1964). The release of insulin from the beta cells of the pancreas is also dependent on the presence of extracellular ionic calcium (Curry, Bennett and Grodsky, 1968). The purpose of this study was to observe alteration in glucose tolerance, insulin release and free fatty acid levels in response to an oral glucose load in hypocalcaemic and normocalcaemic states in the same patients.

\section{Materials and methods}

The subjects for this study comprised two groups: group I consisted of eight female patients having hypocalcaemia due either to primary hypoparathyroidism or vitamin $\mathbf{D}$ deficiency osteomalacia. They were non-obese and non-diabetic and had no family history of these diseases. They were free from gastrointestinal, liver or kidney disease. Group II consisted of ten healthy normal non-diabetics, who 